\title{
FOMITOPSIS PINICOLA IN HEALTHFUL DIETARY APPROACH AND THEIR THERAPEUTIC POTENTIALS
}

\author{
M. Sevindik ${ }^{\mathrm{a}}$, H. Akgul ${ }^{\mathrm{a}}$, I. Akata ${ }^{\mathrm{b}}$, H. Alli ${ }^{\mathrm{c}}$ and Z. Selamoglu ${ }^{\mathrm{d} *}$ \\ ${ }^{a}$ Department of Biology, Faculty of Science, Akdeniz University, Antalya. Turkey \\ ${ }^{b}$ Department of Biology, Faculty of Science, Ankara University, Ankara. Turkey \\ ${ }^{\mathrm{c}}$ Department of Biology, Faculty of Science, Mugla Sitki Kocman University, Mugla. Turkey \\ ${ }^{\mathrm{d}}$ Department of Medical Biology, Faculty of Medicine, Nigde, Omer Halisdemir University, Nigde. Turkey
}

(Received: 5 December 2016; accepted: 4 February 2017)

Certain macrofungi species have been used for medical purposes and as nutrients since the old times. The present study aims to determine and compare total antioxidant status (TAS), total oxidant status (TOS), oxidative stress index (OSI) values, and $\mathrm{Fe}, \mathrm{Zn}, \mathrm{Cu}, \mathrm{Pb}$, and $\mathrm{Ni}$ levels in Fomitopsis pinicola (Sw.) P. Karst samples gathered in Balıkesir province Kazdağı National Park and Yalova province Çınarcık Hasan Baba Woods in Turkey. TAS, TOS, and OSI values of mushroom samples were measured with Rel Assay kits. Mushroom heavy metal content was determined using an atomic absorption spectrophotometer and wet decomposition procedure. In the samples collected from Çinarcık district, OSI values were $0.99 \pm 0.03$, while in the samples collected from Kazdağ $\mathrm{National}$ Park, OSI values were $0.13 \pm 0.01$. Fe content in the samples collected from Çınarcık district were $265.9 \pm 70.5 \mathrm{ppm}$, while Fe content in the samples collected from Kazdağ National Park were $31.31 \pm 1.43$ ppm. As a result, it is considered that the mushrooms could be used as antioxidant source. Furthermore, it could be argued that as a result of the increase in heavy metal levels, the production of oxidants increases in living organisms, which in turn increases the oxidative stress index.

Keywords: Fomitopsis pinicola, oxidative stress, heavy metal, Kazdağı, Çınarcık

In recent years, along with increasing industrial activities, increasing amounts of industrial waste containing metal ions such as mercury, zinc, cobalt, copper, iron, lead, chromium, arsenic, and silver is released into the environment (Tchounwou et al., 2014). As a result of this industrial pollution, heavy metals accumulate in the soil with negative effects on living organisms in the ecosystem (VALIX et al., 2001; ZHANG \& YANG, 2014). Mushrooms could be used as indicators of pollution in nature based on levels of elements they contain in their structure (CоCCHI et al., 2006). It is also known that mushrooms accumulate heavy metals such as copper, mercury, zinc, silver, cadmium, cobalt, lead, manganese, molybdenum, nickel, selenium, cesium, strontium, thallium, and uranium (Liv et al., 2015). Although living organisms require trace amounts of certain elements such as iron, cobalt, copper, manganese, chromium, and zinc, these elements could slow down metabolic reactions or show other toxic effects when they reach high levels (BALDRIAN, 2003; SARIKURKCU et al., 2011). In this context, by investigating mushroom heavy metal levels, it is possible to obtain knowledge whether heavy metals have a negative effect on the living organisms inhabiting the fields where mushrooms grow.

As a result of oxidative stress, which occurs in living organisms due to the effects of environmental and structural factors (LoBO et al., 2010), many health problems could arise in

* To whom correspondence should be addressed.
Phone: +90-388-2253123; fax:+90-388-2252582; e-mail: zselamoglu@ohu.edu.tr

0139-3006 (C) 2017 Akadémiai Kiadó, Budapest 
individuals, including heart diseases, neurological diseases, diabetes, and leukemia (SHAMEEM et al., 2015). Antioxidants produced in the organisms actively prevent damage to cells to reduce the effect of oxidative stress (RAHMAN, 2007). In case of excessive oxidative stress, antioxidants produced in the living organism are not sufficient and antioxidant-rich nutrients should be consumed (PoLJSAK et al., 2013). It is known that mushrooms have antioxidant properties due to different compounds in their structure (BHATIA et al., 2014; GĄSECKA et al., 2016). Determination of the heavy metal level, which is one of the environmental factors responsible for oxidative stress, plays a significant role in identification of hazard levels for living organisms. Furthermore, determination of the amounts of total antioxidants and total oxidants produced in the organisms will contribute to demonstrating the oxidative stress level.

The aims of the present study were to determine the oxidative stress index that demonstrates levels of oxidants against antioxidants in F. pinicola, and also to obtain information about heavy metal contamination and heavy metal pollution in the region.

\section{Materials and methods}

\subsection{Study field}

Whole mushroom bodies of inedible F. pinicola, used for different purposes due to its medical properties (Wu et al., 2014), have been used as experimental material in the study. It is a stem decay mushroom, living on the trunk of trees, which is an important factor influencing its chemical composition. The study material, F. pinicola (Fig. 1), was collected from Pinus nigra J.F.Arnold (Hasan Baba Woods) and from Abies nordmanniana subsp. equi-trojani (Asch. \& Sint. ex Boiss.) Coode \& Cullen (Kazdağ1 National Park). Hasan Baba Woods, which is located at a $20 \mathrm{~km}$ distance from Yalova center and at about $3 \mathrm{~km}$ distance from Çınarcık district, is extensively exposed to anthropogenic effects due to its proximity to the picnic area during the spring and summer seasons. There are no industrial zones near Hasan Baba Woods. On the other hand, Kazdağ 1 National Park is located in the transition zone between Marmara and Aegean regions. These mushrooms were collected from the endemic Kazdağ 1 fir, found $1450 \mathrm{~m}$ high in the National Park of Kazdağ 1 , and there are no residential and industrial zones around this place.

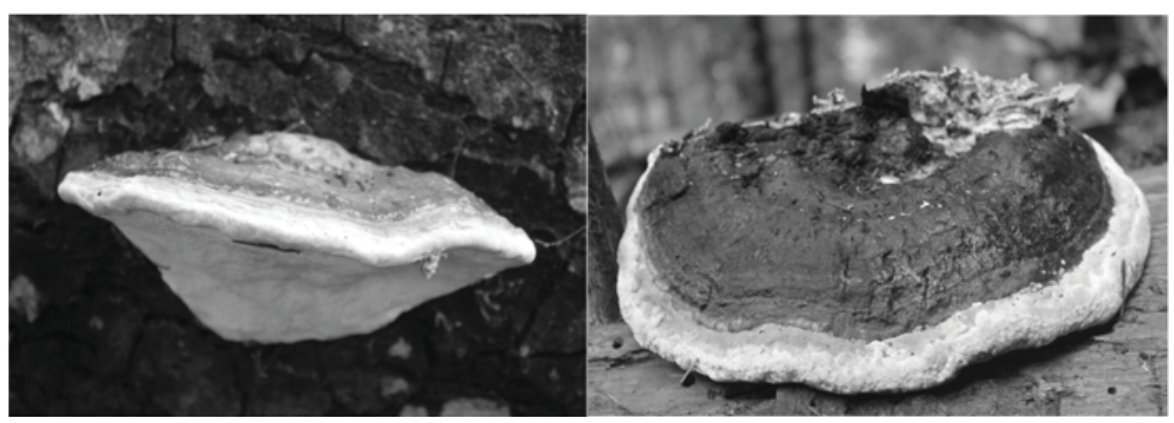

Fig. 1. Fomitopsis pinicola (Sw.) P. Karst 


\subsection{Laboratory study}

The mushrooms collected from each region were brought to the laboratory, dried in an incubator at $40{ }^{\circ} \mathrm{C}$, and pulverized with a mechanical grinder. Then, $30 \mathrm{~g}$ mushroom samples were placed in cartridges, and the extracts were obtained with ethanol in a Soxhlet extractor (Buchi Extraction System Model B-811) at $75{ }^{\circ} \mathrm{C}$ for approximately $6 \mathrm{~h}$. Obtained extracts were condensed under vacuum in a rotary evaporator at $+4{ }^{\circ} \mathrm{C}$ (Buchi Rotavapor Model R-144).

\subsection{Determination of TAS, TOS and OSI values}

Total antioxidant status (TAS) and total oxidant status (TOS) of the mushrooms were measured using Rel Assay brand commercial kit (Rel Assay Kit Diagnostics, Turkey). Analyses were carried out with 5 replicates. For the TAS tests, Trolox, a water-soluble analogue of vitamin $\mathrm{E}$, was used as standard. The results were expressed in terms of millimolar Trolox equivalent per liter (mmol Trolox Equiv./l) (EREL, 2004). For the TOS tests hydrogen peroxide was used as standard. The results were expressed in terms of micromolar hydrogen peroxide equivalent per liter $\left(\mu \mathrm{mol} \mathrm{H}_{2} \mathrm{O}_{2}\right.$ Equiv./l). When the OSI, which is expressed as a percentage of the ratio of TOS levels to TAS levels, was calculated, the mmol value of the TAS test was converted to $\mu \mathrm{mol}$ units utilized in the TOS test (EREL, 2005). The results were calculated based on the following formula:

$$
\mathrm{OSI}=\frac{\mathrm{TOS}, \mu \mathrm{mol} \mathrm{H}_{2} \mathrm{O}_{2}(\text { equiv. } / \mathrm{l})}{\mathrm{TAS}, \text { mmol Trolox equiv./1 } \times 10}
$$

\subsection{Determination of heavy metal content}

Analyses of the mineral content of the mushroom samples were conducted with 3 recurrence wet decomposition methods (Institute of Turkish STANDARDization, 1986a), and with Perkin Elmer (AAS 400) atomic absorption spectrophotometer (InstituTe OF TURKISH Standardization, 1986b). The mushroom samples were dried in an incubator at $80{ }^{\circ} \mathrm{C}$ to constant consistency and then pulverized in a grinder. Three replications of one gram of these samples were weighed and placed in $50 \mathrm{ml}$ glass beakers. Ten millilitres of concentrated $\mathrm{HNO}_{3}$ was added and allowed to stand at room temperature $\left(25^{\circ} \mathrm{C}\right)$ for $24 \mathrm{~h}$. Samples were kept on the heating plate until the residue was thick. Later on, $10 \mathrm{ml}$ of concentrated HCI $(1 \mathrm{~N})$ was added to these pellets, and the decomposition process was repeated. Following the decomposition process, $20 \mathrm{ml}$ of diluted $\mathrm{HCl}(1 \mathrm{~N})$ was added to the samples and they were filtered (SAYGideger Demirors et al., 2013). Heavy metal levels of mushroom samples were given as ppm as a result of the conducted analysis.

\subsection{Statistical analysis}

Standard error values of heavy metal content were determined using Microsoft Excel (2010). Heavy metal contents of mushroom samples were calculated as mean \pm SD.

\section{Results and discussion}

TAS (mmol $\left.1^{-1}\right)$, TOS $\left(\mu \mathrm{mol} \mathrm{1^{-1 }}\right)$, and OSI values of mushroom samples collected from different regions are given in Table 1. 


\begin{tabular}{lccc}
\multicolumn{4}{c}{ Table 1. TAS, TOS, and OSI values } \\
\hline Locality & $\begin{array}{c}\text { TAS } \\
\left(\mathrm{mmol} \mathrm{l}^{-1}\right) \\
(\text { mean } \pm \mathrm{SD})\end{array}$ & $\begin{array}{c}\text { TOS } \\
\left(\mu \mathrm{mol} \mathrm{l}^{-1}\right)\end{array}$ & $\begin{array}{c}\text { OSI } \\
(\text { TOS } /(\mathrm{TAS} \times 10)) \\
(\mathrm{mean} \pm \mathrm{SD})\end{array}$ \\
\hline Çınarcık & $1.44 \pm 0.04$ & $14.21 \pm 0.07$ & $0.99 \pm 0.03$ \\
Kazdağ & $1.57 \pm 0.02$ & $2.03 \pm 0.11$ & $0.13 \pm 0.01$ \\
\hline
\end{tabular}

Values are presented as mean $\pm \mathrm{SD}$; number of mushroom samples $\mathrm{n}=6$, experiments were made in 5 parallels

It was found that total antioxidant status of mushroom samples collected from both regions was similar. However, it was also found that the total oxidant status of Çinarcık samples was higher. Based on determined TOS and TAS values, it was observed that oxidative stress levels were higher in samples collected at Çınarcık. Hence it can be concluded that Kazdağ1 could be considered as more adequate environment in terms of mushroom growth compared to Çınarcık.

Heavy metal contents of mushroom samples are presented in Table 2 as mean \pm SD. It was found that $\mathrm{Fe}$ and $\mathrm{Cu}$ levels in the samples collected from Çınarcık were higher when compared to those collected from the Kazdağ 1 National Park. On the other hand, $\mathrm{Zn}$ and $\mathrm{Pb}$ contents were higher in the samples collected at Kazdağ 1 National Park. Furthermore, it was observed that none of the samples collected contained Ni. The difference in element levels is considered to be due to the different substrates the mushrooms utilized.

\begin{tabular}{lccccc}
\multicolumn{7}{c}{ Table 2. Mushroom heavy metal levels, ppm } \\
\hline Locality & $\begin{array}{c}\mathrm{Fe} \\
(\mathrm{mean} \pm \mathrm{SD})\end{array}$ & $\begin{array}{c}\mathrm{Zn} \\
(\text { mean } \pm \mathrm{SD})\end{array}$ & $\begin{array}{c}\mathrm{Cu} \\
(\text { mean } \pm \mathrm{SD})\end{array}$ & $\begin{array}{c}\mathrm{Pb} \\
(\mathrm{mean} \pm \mathrm{SD})\end{array}$ & $\begin{array}{c}\mathrm{Ni} \\
(\mathrm{mean} \pm \mathrm{SD})\end{array}$ \\
\hline Çınarc1k & $265.9 \pm 70.5$ & $41.27 \pm 2.05$ & $12.53 \pm 3.1$ & $6.45 \pm 1.72$ & $0.00 \pm 0.0$ \\
Kazdaği & $31.31 \pm 1.43$ & $60.61 \pm 5.08$ & $2.30 \pm 0.57$ & $11.83 \pm 1.06$ & $0.00 \pm 0.0$ \\
\hline
\end{tabular}

Values are presented as mean $\pm \mathrm{SD}$; number of mushroom samples $\mathrm{n}=6$; experiments were made as 3 parallels

Aydin and TuRkez (2011) determined TAS and TOS values of Bryoria capillaris, Peltigera rufescens, and Xanthoria elegans lichens collected from Erzurum and Artvin districts. TAS values were 7.09, 6.37, and 7.05 mmol Trolox Equiv./1 and TOS values were 11.63, 11.68, and $11.66 \mu \mathrm{mol} \mathrm{H}_{2} \mathrm{O}_{2}$ Equiv./l, respectively. It can be stated that Kazdağ1 was better than Erzurum and Artvin districts, Erzurum and Artvin districts were better than Çinarcık in terms of oxidative stress, when the result of our study were compared to the study of Aydin and TuRkez (2011). ONAR and co-workers (2016) demonstrated that F. pinicola mushroom can be used as an alternative antioxidant agent, which is in accordance with our findings.

Mushrooms can be used as pollution indicators based on different levels of elements they accumulate in their structure depending on the substrate they use (COCCHI et al., 2006). In a study, Mallikarjuna and co-workers (2013) identified the lowest and highest element content found in the literature for macro-mushrooms as 14.6-835 for Fe, 29.8-158 for Zn, 71-95 for $\mathrm{Cu}$, and 2.86-6.88 ppm for $\mathrm{Pb}$. Compared to the values available in the literature, the values for $\mathrm{Fe}$ and $\mathrm{Zn}$ in the present study were in the same range as mentioned in the 
literature, and $\mathrm{Cu}$ content values were lower in samples obtained from both regions. $\mathrm{Pb}$ content, on the other hand, was found to be at a normal level in the samples collected from Çınarcık and at higher levels in the samples collected from Kazdağ National park when compared to values depicted in the literature.

In general, mushrooms are natural sources possessing medicinal potentials for the production of alternative drugs, natural protective compounds, vitamins, and amino acids. By testing antioxidant capacities of mushroom samples it was found that mushroom could be used as alternative antioxidant agent. Antioxidant and oxidant capacities as well as oxidative stress indices of $F$. pinicola samples related to accumulation of pollutants, such as heavy metals, in different regions were also determined statistically. Finally, the data obtained from this study contribute to the world of science as well as provide very important data on the different composition of mushroom samples and how to use them.

\section{Conclusions}

It was found that samples with high metal levels had high oxidative stress indices as well. Accordingly, the increase in heavy metal levels in living organisms results in an elevated oxidant production.

It was observed that the heavy metal content and total antioxidant and total oxidant levels of the samples collected from Kazdağ National Park were preferable compared to those collected from Çınarcık district Hasan Baba Woods. Although both regions were nature preservation areas, it could be stated that Kazdağ 1 Natural Park was cleaner in terms of heavy metal accumulation. The higher heavy metal contents and OSI values observed could be due to the exposure of Hasan Baba Woods region to high anthropogenic effects. Furthermore, higher TAS values in F. pinicola samples collected from both regions indicated that this mushroom could be used as alternative antioxidant source. Based on the findings of the current study, it could be argued that oxidant production increases with the increase in heavy metal levels, thus, resulting in an increase in the oxidative stress index in living organisms.

\section{References}

Aydin, E. \& Turkez, H. (2011): Effects of lichenic extracts (Bryoria capillaris, Peltigera rufescens and Xanthoria elegans) on human blood cells: A cytogenetic and biochemical study. Fresen. Environ. Bull., 20, 2992-2998.

BALdRIAN, P. (2003): Interactions of heavy metals with white-rot fungi. Enzyme Microb. Tech., 32, 78-91.

Bhatia, P., Bansal, C., Prakash, R. \& Nagaraja, T.P. (2014): Selenium uptake and associated anti-oxidant properties in Pleurotus fossulatus cultivated on wheat straw from seleniferous fields. Acta Alimentaria, 43, $280-287$.

Cocchi, L., Vescovi, L., Petrini, L.E. \& Petrini, O. (2006): Heavy metals in edible mushrooms in Italy. Food Chem., 98, 277-284.

EREL, O. (2004): A novel automated direct measurement method for total antioxidant capacity using a new generation, more stable ABTS radical cation. Clin. Biochem., 37, 277-285.

Erel, O. (2005): A new automated colorimetric method for measuring total oxidant status. Clin. Biochem., 38, 1103-1111.

Gąsecka, M., Mleczek, M., Siwulski, M., Niedzielski, P. \& Kozak, L. (2016): Phenolic and flavonoid content in Hericium erinaceus, Ganoderma lucidum, and Agrocybe aegerita under selenium addition. Acta Alimentaria, 45, 300-308.

InSTITUTE of TURKISH STANDARDIZATION (1986a): Fruits, vegetables and derived products - Decomposition of organic matter prior to analysis - Wet method. TS 4887. 
Institute of Turkish Standardization (1986b): Fruits, vegetables and derived products - Determination of zinc content - Atomic absorption spectrophotometric method. TS 7573.

Liu, B., Huang, Q., Cai, H., Guo, X., Wang, T. \& Gui, M. (2015): Study of heavy metal concentrations in wild edible mushrooms in Yunnan province, China. Food Chem., 188, 294-300.

Lobo, V., Patil, A., Phatak, A. \& Chandra, N. (2010): Free radicals, antioxidants and functional foods: Impact on human health. Pharmacogn. Rev., 4(8), 118-126.

Mallikarjuna, S.E., Ranjini, A., Haware, D.J., Vijayalakshmi, M.R., Shashirekha, N.M. \& Rajarathnam, S. (2013): Mineral composition of four edible mushrooms. J. Chem., 1, 1-5. Article ID 805284.

Onar, O., Akata, I., Sagdicoglu Celep, G. \& Yildirim, O. (2016): Antioxidant activity of extracts from the red-belt conk medicinal mushroom, Fomitopsis pinicola (Agaricomycetes), and its modulatory effects on antioxidant enzymes. Int. J. Med. Mushrooms, 8, 501-508.

Poljsak, B., Sput, D. \& Milisav, I. (2013): Achieving the balance between ROS and antioxidants: When to use the synthetic antioxidants. Oxid. Med. Cell. Longev., 2013, 1-11.

Rahman, K. (2007): Studies on free radicals, antioxidants, and co-factors. Clin. Interv. Aging, 2(2), 219-236.

Sarikurkcu, C., Copur, M., Yildiz, D. \& Akata, I. (2011): Metal concentration of wild edible mushrooms in Soguksu National Park in Turkey. Food Chem., 128, 731-734.

Saygideger Demirors, S., Keser, G. \& DoĞan, M. (2013): Effects of lead on chlorophyll content, total nitrogen, and antioxidant enzyme activities in duckweed (Lemna minor). Int. J. Agric. Biol., 15, 145-148.

Shameem, N., Kamili, N.A., Ahmad, M., Masoodi, F.A. \& Parray, J.A. (2015): Radical scavenging potential and DNA damage protection of wild edible mushrooms of Kashmir Himalaya. J. Saudi Soc. Agric. Sci., 1, 1-8.

Tchounwou, P.B., Yedjou, C.G., Patlolla, A.K. \& Sutton, D.J. (2014): Heavy metals toxicity and the environment. EXS, 101, 133-164.

Wu, H.T., Lu, F.H., Su, Y.C., Ou, H.Y., Hung, H.C., Wu, J.S., Yang, Y.C. \& Chang, C.J. (2014): In vivo and in vitro anti-tumor effects of fungal extracts. Molecules, 19, 2546-2556.

Valix, M., TANG, J.Y. \& MaliK, R. (2001): Heavy metal tolerance of fungi. Miner. Eng., 14, 499-505.

ZhANG, Y. \& YANG, G. (2014): Heavy metal contents of some wild edible mushrooms from Miyi, China. Appl. Mech. Mater., 490-491, 142-145. 